Original

Article

\section{Surgical management of renal cell carcinoma with inferior vena caval thrombus: A teaching hospital experience}

\author{
Kulkarni Jagdeesh N, Acharya Purushothama U, Rizvi S Jamal, Somaya Anand C* \\ Departments of Genito-Urinary Surgery and ${ }^{*}$ Cardio Vascular Surgery, Bombay Hospital Institute of \\ Medical Sciences, Mumbai, India
}

Correspondence to: Jagdeesh Kulkarni, E-mail: jnkulkarni@hotmail.com

\title{
Abstract
}

PURPOSE: To evaluate the outcome of patients of renal cell carcinoma (RCC) with inferior vena caval (IVC) thrombus treated by radical nephrectomy and IVC thrombectomy in terms of clinical and pathological factors and prognosis. MATERIALS AND METHODS: Sixty-three consecutive patients of RCC with IVC thrombus who underwent radical nephrectomy with IVC thrombectomy between June 1993 and May 2003 were included in this retrospective analysis. Data was analyzed in terms of clinical factors, such as level of thrombus, and pathological factors, such as grade, local invasion and $\mathrm{N}$ status. RESULTS: Tumor thrombus level was infrahepatic in 35 patients, retrohepatic in 20 and suprahepatic in 8 , including 5 with right atrial thrombus. The immediate post-operative mortality was $3 \%$, and the incidence of major post-operative complications was 34\%, but most of them improved after conservative management except one who needed surgery for burst abdomen. The disease free survival (DFS) was $48.5 \%, 50.6 \%, 66.6 \%$ and $40 \%$ for infrahepatic, retrohepatic, suprahepatic and intra-atrial tumors, respectively. Of the histological types, patients with clear cell tumors had the best prognosis; those with granular cell had the worst prognosis (DFS of $53.5 \%$ vs $33.3 \%$, though statistically not significant). Grade-2 tumors had better prognosis than grade-4 tumors (DFS 66.6\% vs $0 \%, P<0.001$ ). Sixty-eight percent of patients without perinephric fat invasion were free of disease as compared to $31 \%$ of those with perinephric fat invasion $(P<0.01)$. Further, $\mathrm{N}$ status showed DFS of $60.9 \%$ in patients with negative nodes and $30 \%$ in patients with positive nodes $(P<0.05)$. CONCLUSION: Though surgery for RCC with IVC thrombus has high morbidity, it can give good results in terms of prolonged DFS in expert hands. Regarding long-term survival, pathological factors, such as local stage and grade, are more important than clinical factors, such as level of thrombus.

Key words: Carcinoma, inferior, prognosis, renal cell, vena cava

\section{Introduction}

Renal cell carcinoma (RCC) with inferior vena caval (IVC) thrombus is a complex surgical problem, which is seen in $4-10 \%$ of cases of patients with RCC. ${ }^{[1-3]}$ Earlier, it was considered an inoperable 'death sentence'. In 1970s, Skinner et al. ${ }^{[4]}$ showed that good long-term results could be obtained with surgical management in the absence of metastasis. In developing countries like India, many patients report at a later stage of natural history - which is partly due to lower socio-economic status, lack of health awareness on the part of patients, and inaccessibility to the centers where such major surgeries are done, as very few centers in India have such facilities. Here, we review our experience with such cases - the presentation, the principles of surgical management that we followed, the results and the prognostic factors affecting survival.

\section{Materials and Methods}

Sixty-three consecutive patients who underwent surgery for RCC with IVC thrombus between 1993 and 2003 were included in this retrospective study. Those who 
were not operated were excluded from this study. Those with metastasis were not operated because they had poor overall survival, ${ }^{[4]}$ though recent reports suggest that even those with solitary metastasis can be operated with good results ${ }^{[5,6]}$ especially if one is planning for immunotherapy. Standard preoperative investigations and preparations were carried out. American Joint Committee on Cancer staging system $(\mathrm{TNM})^{[7]}$ was used for staging, and Fuhrman criteria ${ }^{[8]}$ were used for histopathologic grading. The surgery was a joint venture of uro-oncologist and vascular surgeons and performed in a cardiac theatre with continuous arterial and central venous pressure and end tidal carbon dioxide monitoring. All patients underwent surgery by midline abdominal incision from xiphisternum to symphysis pubis. Those with difficult retrohepatic extension (such as presence of gross hepatomegaly or very obese patients) and those with suprahepatic extension underwent median sternotomy for control/or temporary occlusion of intrapericardial IVC. For those tumors with supradiaphragmatic or right atrial extension, cardiopulmonary bypass with deep hypothermic circulatory arrest was used. The standard surgical techniques were followed for mobilization and exposure, thrombectomy and repair. Patients were followed up as per the protocol prevailing at that period of time. The presenting symptoms and signs, the imaging study findings, the operative findings, especially regarding the level of thrombus, the approach, postoperative complications, the final histopathologic stage and grade, and the follow up findings were recorded. Chi-square analysis was used to calculate the statistical significance/P-value.

\section{Results}

Inferior vena caval extension of tumor was seen in $11.6 \%$ of all patients with RCC [Table 1]. The mean age of patient was 54.2 years (23-92 years). There were 46 males and 17 females. There was almost 2:1 ratio of right- and left-sided tumors. One or more of the triad of hematuria, mass or pain was seen in $61.9 \%$ of the patients, but it is important to note that 24 patients had non-specific symptoms and, of these, 7 patients were asymptomatic with respect to the tumor. The average duration of symptoms was 14.4 weeks. On examination, majority $(85.7 \%)$ had a palpable mass and about a third had varicocele and/or edema. The paraneoplastic syndromes observed were similar to the ones reported in literature ${ }^{[9]}$ except that, in our series, there was a high incidence of jaundice/ alterations in liver enzymes $(28.5 \%)$. Since most were referred patients who came up with different types of imaging studies of different qualities over different time periods in the 15 years, it was difficult to correlate the findings of imaging studies with operative or

\begin{tabular}{|c|c|c|}
\hline $\begin{array}{l}\% \text { of patients with RCC } \\
\text { having IVC thrombus }\end{array}$ & & $11.2 \%$ \\
\hline Age & & $\begin{array}{c}\text { Mean - } 54.2 \text { years } \\
(13-92 \text { years })\end{array}$ \\
\hline Sex (male: female) & & $46: 17$ \\
\hline Side (R:L) & & $40: 23$ \\
\hline Symptoms & No. & $\%$ of total \\
\hline Pain & 12 & 19.04 \\
\hline Hematuria & 23 & 36.50 \\
\hline Mass & 4 & 6.34 \\
\hline PUO & 7 & 11.11 \\
\hline Anorexia/weight loss & 10 & 15.87 \\
\hline $\begin{array}{l}\text { Non-specific } \\
\text { (e.g. Malaria, piles } \\
\text { bleeding etc.) }\end{array}$ & & 11.11 \\
\hline
\end{tabular}

Signs

\begin{tabular}{lll}
\hline Cachexia & 15 & 23.80 \\
\hline Hypertension & 16 & 25.39 \\
\hline Anemia & 21 & 33.33 \\
\hline Mass & 54 & 85.71 \\
\hline Edema/varicocoele & 20 & 31.74 \\
\hline
\end{tabular}

Paraneoplastic syndromes

\begin{tabular}{lcc}
\hline Hypertension & 16 & 25.39 \\
\hline Anemia & 21 & 33.33 \\
\hline Elevated liver enzymes & 18 & 28.57 \\
\hline Hypercalcemia & 3 & 4.76 \\
\hline Raised ESR & 42 & 66.66 \\
\hline
\end{tabular}

RCC - Renal cell carcinoma, IVC - Inferior vena caval

histopathologic findings, but the level of thrombus was usually consistent with the findings in imaging studies. Midline abdominal incision only was used in 45 patients [Table 2] and additional sternotomy in 18 patients, of which 6 patients with deep hypothermic circulatory arrest needed cardiopulmonary bypass. The mean operative time for midline abdomen approach was $4.1 \mathrm{~h} ; 5.3 \mathrm{~h}$ for additional sternotomy cases; and $6.8 \mathrm{~h}$ when hypothermic circulatory arrest was used for atrial thrombus. The mean blood transfusion was 3.1 units, 3.8 units and 5.6 units, respectively, for these three levels of approaches. Post-operatively, 10 patients had transient renal dysfunction [Table 3], 4 patients

\begin{tabular}{|c|c|c|c|}
\hline Approach & Level of thrombus & No. & $\%$ of total \\
\hline \multirow[t]{2}{*}{ Midline abdomen } & Infrahepatic & 35 & 55.55 \\
\hline & Retrohepatic & 10 & 31.74 \\
\hline \multirow{2}{*}{$\begin{array}{l}\text { Additional } \\
\text { sternotomy only }\end{array}$} & Retrohepatic & 10 & \\
\hline & Suprahepatic & 2 & 4.76 \\
\hline \multirow[t]{2}{*}{ Additional CPB } & Suprahepatic & 1 & \\
\hline & Right atrial & 5 & 7.93 \\
\hline
\end{tabular}


Table 3: Perioperative complications

\begin{tabular}{lcc}
\hline Complications & No. & $\%$ of total \\
\hline Pneumonia/sepsis/MODS & $4(1$ death $)$ & 6.34 \\
\hline Transient renal failure & 10 & 15.87 \\
\hline CVA & $3(1$ death $)$ & 4.76 \\
\hline Intestinal obstruction & 3 & 4.76 \\
\hline Malaria & 1 & 1.58 \\
\hline Burst abdomen & 1 & 1.58 \\
\hline Overall morbidity & 22 & 34.92 \\
\hline Total mortality & 2 & 3.17 \\
\hline
\end{tabular}

had sepsis, another 3 had cerebrovascular accident, and one had prolonged fever, which turned out to be malaria. Two patients had intestinal obstruction 6 months and 2 years, respectively, after surgery - of all these patients, two died and the rest improved with conservative management. Of the two patients who died in the post-operative period, one died of sepsis with fulminant hepatitis and multiple organ dysfunction - he was a known case of pre-operatively stable chronic hepatitis - and the other died due to cerebrovascular accident. One patient was operated for abdominal wound dehiscence. The average duration of hospital stay was 8.2, 10.6 and 12.2 days, respectively, for three levels of approach. The histopathology showed that majority $(73 \%)$ of patients had clear cell type [Table 4] with or without granular differentiation (46 of 63 ), whereas 9 patients (14.2\%) had pure granular cell type and 8 (12.6\%) had papillary type. Grade-2 tumors were seen in $25(39.6 \%)$ patients, grade-3 tumors in $34(53.9 \%)$, and grade- 4 tumors $(6.3 \%)$ in 4 patients. The average tumor size was $11.1 \mathrm{~cm}$ (range of $5-17 \mathrm{~cm}$ ). Ten patients $(15.8 \%$ ) had tumors not reaching the capsule, $24(38 \%)$ had only capsular invasion, and $29(46 \%)$ had invasion of perinephric fat. Lymph node involvement was seen in 20 patients $(31.7 \%)$. Adrenal gland was involved in 5 patients, and 7 had invasion of the wall of IVC or renal vein, of which 3 patients with gross involvement of IVC wall underwent partial resection of the involved segment and primary repair without the use of grafts. During follow ups [Table 5] for 24 to 144 months (median of 60 months), 31 patients $(49.2 \%)$ were alive without metastasis, $9(14.2 \%)$ were alive with metastasis,

\begin{tabular}{lcc}
\hline Table 5: Follow up (\% of total) & & \\
\hline Immediate post-operative mortality & 2 & 3.17 \\
\hline Alive without disease & 31 & 49.20 \\
\hline Alive with metastasis & 9 & 14.28 \\
\hline Died during follow up & 13 & 20.63 \\
\hline Lost to follow up & 8 & 12.69 \\
\hline Disease free survival & 31 & 49.20 \\
\hline Over all survival & 40 & 63.49 \\
\hline
\end{tabular}

$13(20.6 \%)$ had died - mostly of metastasis (in lungs and bones) - and 8 were lost for follow up. Fifty-four percent of male patients and $41 \%$ of female patients had disease free survival (DFS) [Table 6]. Forty-six percent of patients with right-sided tumors and $59 \%$ of patients with left-sided tumors had DFS. With tumors larger than $10 \mathrm{~cm}, 45.7 \%$ were alive without disease as compared to $53.5 \%$ of those with tumors smaller than $10 \mathrm{~cm}$. Of 35 patients with infrahepatic level of thrombus, $48.5 \%$ were alive without disease, as were $50 \%$ of 20 patients with retrohepatic disease and 4 of 6 patients with suprahepatic IVC involvement including 2 of 5 patients with atrial extension (excluding 2 patients with suprahepatic extension who died in the immediate postoperative period). More than half the patients with clear cell tumors were alive without metastasis [Table 7] whereas only one-third of granular cell type had DFS. Two-third of patients with grade- 2 tumors were alive without metastasis, whereas less than half the patients with grade- 3 tumors were alive without metastasis, and none were alive with grade- 4 tumors. Sixty-eight percent of patients without perinephric involvement [Tables 7 and 8 ] had DFS, whereas only $31 \%$ of patients with perinephric fat invasion were alive without disease. Of those with lymph node involvement, $30 \%$ had DFS whereas $60 \%$ of those without lymph node invasion were alive without disease. Only one patient with adrenal (20\%) and 2 of 7 patients $(28.5 \%)$ with vessel wall invasion were alive at follow up.

\section{Discussion}

The surgical management of RCC with extension into IVC is a challenging one, which can be undertaken only

\section{Table 4: Pathology}

\begin{tabular}{lccccc}
\hline Tumour type & No. (\%) & Tumor grade & No. (\%) & Local stage & No. (\%) \\
\hline Clear cell & $30(47.61)$ & I & - & Capsule neg. & 10 (15.87) \\
\hline Granular & $9(14.28)$ & II & $25(39.68)$ & Capsule pos. \\
\hline Mixed & $16(25.39)$ & III & $34(53.96)$ & Perinephric pos. & $29(46.03)$ \\
\hline Papillary & $8(12.69)$ & IV & $4(6.34 \%)$ & Node pos. & $20(31.74)$ \\
\hline
\end{tabular}


Table 6: Clinical factors and disease free survival (Excluding 2 post-operative deaths)

\begin{tabular}{lccc}
\hline Clinical factor & $\begin{array}{c}\text { No. of } \\
\text { patients }\end{array}$ & $\begin{array}{c}\text { No. of patients } \\
\text { with DFS }\end{array}$ & \% DFS \\
\hline Overall & 61 & 31 & 50.81 \\
\hline Sex & & & \\
\hline Male & 44 & 24 & 54.54 \\
\hline Female & 17 & 7 & 41.17 \\
\hline Side & & & \\
\hline Right & 39 & 18 & 46.1 \\
\hline Left & 22 & 13 & 59.04 \\
\hline Clinical presentation & & & \\
\hline Hematuria & 12 & 5 & 41.66 \\
\hline Pain & 23 & 13 & 56.52 \\
\hline Mass & 4 & 2 & 50.00 \\
\hline Cachexia/anemia & 21 & 7 & 33.33 \\
\hline Hypertension & 16 & 9 & 56.25 \\
\hline Raised liver enz. & 18 & 5 & 27.77 \\
\hline Raised ESR & 42 & 18 & 42.85 \\
\hline Hypercalcemia & 3 & 1 & 33.33 \\
\hline Level of thrombus & & & \\
\hline Infrahepatic & 35 & 17 & 48.50 \\
\hline Retrohepatic & 20 & 10 & 50.00 \\
\hline Suprahepatic & 6 & 4 & 66.66 \\
\hline
\end{tabular}

where proper facilities and expertise are available. There are very few tertiary care centers in India where surgery of such a magnitude can be carried out. The overall 3- to 5 -year survival reported in the literature varies between 25 and $84 \%^{[2,4,5,10-13]}$ and with a multitude of factors. In this retrospective study, we have tried to present the pattern of clinical picture seen in our country as well as correlate between various prognostic factors reported in the literature and the survival in our patients.

The clinical presentation of patients in this series including age, sex, side, level of thrombus, etc. was not much different from that reported in the literature ${ }^{[4,14-17]}-\mathrm{a}$ majority of our patients presented with one or more of the symptom triad of hematuria, flank pain or mass per abdomen. In addition, quite a significant proportion of patients presented with non-specific symptoms or was totally asymptomatic with respect to the tumor. The only different feature was the higher incidence of abnormal liver function tests as compared to those with RCC reported in the literature, ${ }^{[9]}$ which may either be due to Stauffer syndrome or back pressure created on the hepatic veins by the tumor thrombus - which sometimes can cause Budd-Chiari syndrome or even liver failure, ${ }^{[18]}$ though this was not observed in our patients. In addition, the number of patients with RCC having tumor thrombus (11.6\%) was higher than the $4-10 \%$
Table 7: Pathologic variable vs disease free survival (Excluding 2 post-operative deaths)

\begin{tabular}{lccc}
\hline Pathologic factor & $\begin{array}{c}\text { No. of } \\
\text { patients }\end{array}$ & $\begin{array}{c}\text { No. of patients } \\
\text { with DFS }\end{array}$ & \% DFS \\
\hline Overall & 61 & 31 & 50.81 \\
\hline Tumor type & & & \\
\hline Clear cell & 28 & 15 & 53.57 \\
\hline Granular cell & 9 & 3 & 33.33 \\
\hline Mixed & 16 & 9 & 56.25 \\
\hline Papillary & 8 & 4 & 50.00 \\
\hline Tumor grade & & & \\
\hline Grade II & 24 & 16 & 66.66 \\
\hline Grade III & 33 & 15 & 45.45 \\
\hline Grade IV & 4 & 0 & - \\
\hline Local stage & & & \\
\hline Perinephric neg. & 32 & 22 & 68.75 \\
\hline Perinephric pos. & 29 & 9 & 31.03 \\
\hline Node neg. & 41 & 25 & 60.97 \\
\hline Node pos. & 20 & 6 & 30.00 \\
\hline Adrenal pos. & 5 & 1 & 20.00 \\
\hline IVC wall invasion pos. & 7 & 28.57 \\
\hline DFS - Disease free survival & & & \\
\hline
\end{tabular}

Table 8: Local stage vs disease free survival

\begin{tabular}{lccc}
\hline Stage & $\begin{array}{c}\text { No. of } \\
\text { patients }\end{array}$ & $\begin{array}{c}\text { No. of patients } \\
\text { with DFS }\end{array}$ & \%DFS \\
\hline $\mathrm{pT}_{3 b, \mathrm{c}} \mathrm{No}$ & 28 & 19 & 67.85 \\
$\mathrm{pT}_{4} \mathrm{No}$ & 13 & 6 & 46.15 \\
$\mathrm{pT}_{3 \mathrm{~b}, \mathrm{c}} \mathrm{N}+$ & 8 & 3 & 37.50 \\
$\mathrm{pT}_{4} \mathrm{~N}+$ & 12 & 3 & 25.00 \\
\hline
\end{tabular}

mentioned in the literature, ${ }^{[1-3]}$ which may be due to delayed presentation in our patient population or due to the fact that, being a referral center, only complex cases such as those with venous thrombus are referred to our center. Thirty-five of 63 tumors were infrahepatic, which were explored by midline abdominal incision. Half the intrahepatic tumors were considered 'difficult' due to various reasons intraoperatively in spite of complete mobilization of liver and needed median sternotomy for control of suprahepatic vena cava and Pringle's maneuver was used in all such patients which can be used safely up to $20 \mathrm{~min}$. One of the three patients with suprahepatic thrombus needed cardiopulmonary bypass, whereas two could be removed without cardiopulmonary or venovenous bypass, the latter being not used in any patient as the chance of troublesome bleeding is more with veno-venous bypass than with cardiopulmonary bypass with deep hypothermic circulatory arrest in which one can operate in total bloodless field and is safe for up to $40 \mathrm{~min}$, and our cardiovascular colleagues are well versed with this technique. There was no operative mortality. 
The incidence of major postoperative complications was $38 \%$, which may be somewhat more than that reported in the literature. ${ }^{[6,10,15,19]}$ This may partly be due to the less-than-optimal preoperative status of our patients for example, 6 of the 10 patients with post-operatively raised creatinine had preoperative creatinine of more than $1.3 \mathrm{mg} / \mathrm{dl}$; the patient with burst abdomen was cachectic with hypoproteinemia and complications such as malaria are common in developing countries. All except two recovered from these complications - one died of worsening of preoperatively stable chronic hepatitis and the other died of cerebrovascular accident; he was hypertensive. The perioperative mortality of $3.1 \%$ was well within the acceptable range reported in the literature ${ }^{[6,12,19]}$ as is the overall survival of $63.5 \%$ and $49.2 \%$ of DFS..$^{[2,4,5,10-13]}$ Very few patients received interferon as it was unaffordable in our setup.

When we tried to correlate the clinical presentation with the DFS, we noted that sex, side, size and type of presentation were not significantly associated with prognosis. Patients with abnormal liver function tests and those with cachexia had poor survival. Review of literature ${ }^{[3,5,8,10-18]}$ indicates conflicting reports regarding several important clinical prognostic factors such as size of tumor, type of presentation including the presence of hematuria, raised ESR/platelets, symptomatic presentation and level of thrombus. For example, Golimbu et al.[5] noted that size of the tumor is an important prognostic factor, whereas Fuhrman et al. ${ }^{[8]}$ noted that size of the tumor influences survival because it correlates with the grade of the tumor. In addition, though earlier reports indicated that the level of thrombus is an important prognostic factor, ${ }^{[15]}$ later literature ${ }^{[3,10,12,16]}$ suggested that the level is not important - which is supported by our observations as well (DFS of $48.5 \%, 50 \%, 66.6 \%$ and $40 \%$ for infrahepatic, retrohepatic, suprahepatic and intra-atrial tumors, respectively). But again, recent literature indicates that renal vein thrombus may have better prognosis than IVC thrombus. ${ }^{[14,17]}$

Several pathologic prognostic factors are mentioned in the literature, ${ }^{[2,5,11-13,16,20]}$ including mainly the local stage of tumor, histological type and grade ${ }^{[8,11]}$ of tumor and presence of vascular invasion, ${ }^{[13]}$ vessel wall invasion, ${ }^{[2]}$ adrenal and pelvicalyceal system invasion, ${ }^{[5,20]}$ nuclear morphometry, DNA ploidy, ${ }^{[11]}$ etc.

Comparing the pathologic prognostic factors with survival, we noted that patients with clear cell tumors had the best prognosis, those with granular cell had the worst prognosis (DFS of $53.5 \%$ vs $33.3 \%$, respectively, though statistically not significant), and those with papillary and mixed clear and granular cell types had intermediate prognosis. Moreover, as in literature, ${ }^{[8,11]}$ grade- 2 tumors had better prognosis than grade- 4 tumors (66.6\% vs $0 \%$ DFS, $\mathrm{P}<0.001$, statistically significant). Local stage probably is the most important prognostic factor ${ }^{[2,11-13,16]}$ in our series, $68.75 \%$ of patients without perinephric fat invasion were free of disease as compared to $31 \%$ in those with perinephric fat invasion $(P<0.01$, statistically significant). In addition, $60.9 \%$ of patients without lymph node invasion were free of disease at follow up as compared to $30 \%$ when lymph nodes were positive $(P<0.05$, statistically significant). Hatcher et al. noted that vessel wall invasion is more important than the level of thrombus, and resection of IVC wall improved survival. ${ }^{[2,19]}$ In our series, seven patients had invasion of either renal vein or IVC wall, which was resected, of which two were alive at follow up. Another important prognostic factor was the involvement of adrenal gland. In our series, five patients had adrenal involvement (of which one was due to metastasis from a lower polar tumor), but only one patient survived - though it may be difficult to draw conclusion from this study as the number of patients with vessel wall or adrenal invasion was small.

\section{Conclusions}

Renal cell carcinoma with IVC extension is one of the most complicated surgical challenges, but excellent results can be obtained with proper patient selection, meticulous techniques of surgery and close perioperative patient care in a tertiary care setup. Pathological factors, such as locoregional stage and grade of tumor, rather than clinical factors, such as level of thrombus, influence survival. Morbidity and mortality in our series was well within the acceptable limits reported in the literature, but regular and long-term follow up is needed to know whether the initial success is long lasting.

\section{References}

1. Marshall VF, Middleton RG, Holswade GR, Goldsmith El. Surgery for renal cell carcinoma in the vena cava. J Urol 1970;103: 414-20.

2. Hatcher PA, Anderson EE, Paulson DF, Carson CC, Robertson JE. Surgical management and prognosis of renal cell carcinoma invading the vena cava. J Urol 1991;145:20-4.

3. Casanova GA, Zingg EJ. Inferior vena caval tumor extension in renal cell carcinoma. Urol Int 1991;47:216-8.

4. Skinner DG, Pritchett TR, Lieskovsky G, Boyd SD, Stiles QR. Vena caval involvement by renal cell carcinoma: Surgical resection provides meaningful long-term survival. Ann Surg 1989;210: 387-94.

5. Golimbu M, Joshi P, Sperber A, Tessler A, Al-Askari S, Morales P. Renal cell carcinoma: Survival and prognostic factors. Urology 1986;27:291-301.

6. Zisman A, Pantuck AJ, Chao DH, Wieder JA, Dorey F, Said JW, et al. Renal cell carcinoma with tumor thrombus: Is cytoreductive nephrectomy for advanced disease associated with an increased 
complication rate? J Urol 2002; 168:962-7.

7. Guinan P, Sobin LH, Algaba F, Badellino F, Kameyama S, MacLennan G, et al. TNM staging of renal cell carcinoma: Workgroup No 3 Union International Contre le Cancer (UICC) and the American Joint Committee on Cancer (AJCC). Cancer 1997;80:992-3.

8. Fuhrman SA, Lasky LC, Limas C. Prognostic significance of morphologic parameters in renal cell carcinoma. Am J Surg Pathol 1982;6:655-63.

9. Chisolm GD. Nephrogenic ridge tumors and their syndrome. Ann NY Acad Sci 1974;230:403-23

10. Staehler G, Brkovic D. The role of radical surgery for renal cell carcinoma with extension into the vena cava. J Urol 2000;163:1671-5.

11. Thrasher JB, Paulson DF. Prognostic factors in renal cancer. Urol Clin North Am 1993;20:247-62.

12. Glazer AA, Novick AC. Long-term followup after surgical treatment for renal cell carcinoma extending into the right atrium. J Urol 1996; 155:448-50.

13. Zisman A, Wieder JA, Pantuck AJ, Chao DH, Dorey F, Said JW, et al. Renal cell carcinoma with tumor thrombus extension: Biology, role of nephrectomy and response to immunotherapy. J Urol 2003; 169:909-16.

14. Blute ML, Leibovich BC, Lohse CM, Cheville JC, Zincke H. Mayo Clinic experience with surgical management, complications and outcome for patients with renal cell carcinoma and venous tumour thrombus. BJU Int 2004;94:33-41.

15. Sosa RE, Muecke EC, Vaughan ED Jr, McCarron JP Jr. Renal cell carcinoma extending into the inferior vena cava: The prognostic significance of the level of vena caval involvement. J Urol 1984; 132: 1097-100.

16. Tongaonkar HB, Dandekar NP, Dalal AV, Kulkarni JN, Kamat MR. Renal cell carcinoma extending to the renal vein and inferior vena cava: Results of surgical treatment and prognostic factors. J Surg Oncol 1995;59:94-100.

17. Moinzadeh A, Libertino JA. Prognostic significance of tumor thrombus level in patients with renal cell carcinoma and venous tumor thrombus extension: Is all T3b the same? J Urol 2004; 171:598-601.

18. Ciancio G, Soloway M. Renal cell carcinoma invading the hepatic veins. Cancer 2001;92:1836-42.

19. Montie JE, el Ammar R, Pontes JE, Medendorp SV, Novick AC, Streem SB, et al. Renal cell carcinoma with inferior vena cava tumor thrombi. Surg Gynecol Obstet 1991;173:107-15.

20. Uzzo RG, Cherullo EE, Myles J, Novick AC. Renal cell carcinoma invading the urinary collecting system: Implications for staging. J Urol 2002; 167:2392-6.

\section{Source of Support: Nil, Conflict of Interest: None declared.}

\section{Author Help: Online Submission of the Manuscripts}

Articles can be submitted online from http://ww w.journalonw eb.com. For online submission articles should be prepared in tw o files (first page file and article file). Images should be submitted separately.

1) First Page File:

Prepare the title page, covering letter, acknow ledgement, etc., using a word processor program. All information which can reveal your identity should be here. Use text/rtf/doc/pdf files. Do not zip the files.

2) Article file:

The main text of the article, beginning from Abstract till References (including tables) should be in this file. Do not include any information (such as acknow ledgement, your names in page headers, etc.) in this file. Use text/rtf/doc/pdf files. Do not zip the files. Limit the file size to $400 \mathrm{~kb}$. Do not incorporate images in the file. If file size is large, graphs can be submitted as images separately without incorporating them in the article file to reduce the size of the file.

3) Images:

Submit good quality colour images. Each image should be less than $400 \mathrm{~kb}$ in size. Size of the image can be reduced by decreasing the actual height and width of the images (keep up to about 4 inches) or by reducing the quality of image. All image formats (jpeg, tiff, gif, bmp, png, eps, etc.) are acceptable; jpeg is most suitable. The image quality should be good enough to judge the scientific value of the image. Always retain a good quality, high resolution image for print purpose. This high resolution image should be sent to the editorial office at the time of sending a revised article.

4) Legends:

Legends for the figures/images should be included at the end of the article file. 